\title{
NORWEGIAN SOCIETY FOR THE HISTORY OF MEDICINE
}

ThE Society held its first meeting of the year on 13 April, when Miss Mirsten Bergh read a paper on the trials for witchcraft held in Norway from the fifteenth to seventeenth centuries. Miss Bergh dealt especially with the series of trials which took place about 1670 in Finnmark county. In the small town of Vardoe no less than twenty women were burnt as witches during a period of five months.

At the same meeting Mr. N. A. Sverre read a paper on the historical relations between the physician and the apothecary.

BERNHARD GETZ

\section{News, Notes and Queries}

\section{THE MILITARY GENERAL SERVICE MEDAL AWARDED TO BRANSBY GOOPER ( $1792-1853$ )}

by

K. F. RuSSELL

IN 1848 the survivors of those who had served in the war with France received belated recognition from the Queen. Hostilities had ceased in 1815 with the battle of Waterloo when the Prince Regent had immediately authorized the issue of a medal for all ranks present at this battle as a mark of esteem from a grateful government. It is true that the Duke of Wellington and his senior officers had received many distinctions for their services in the campaigns preceding Waterloo but the junior officers and rank and file were forgotten. There is plenty of evidence to show that the Iron Duke himself strenuously opposed the award of any distinction to the very men who made victory possible.

It was entirely due to the efforts of the Duke of Richmond in arousing the sympathy of Queen Victoria that this injustice was removed by a General Order being published on the Ist of June, 1847 authorizing the issue of a medal to all ranks of both Army and Navy. The Military General Service Medal covered fighting during the period 1808-14, later to be extended to include the campaign in Egypt in 180r; the Naval General Service Medal was for Service from 193 to 1840 . Thus at long last the survivors were able to wear with pride some tangible evidence of their long and arduous service, and many thousands made good their claims.

Among the many medical officers to receive the Military General Service Medal was Bransby Blake Cooper (1792-1853) so well know as an anatomist and surgeon 


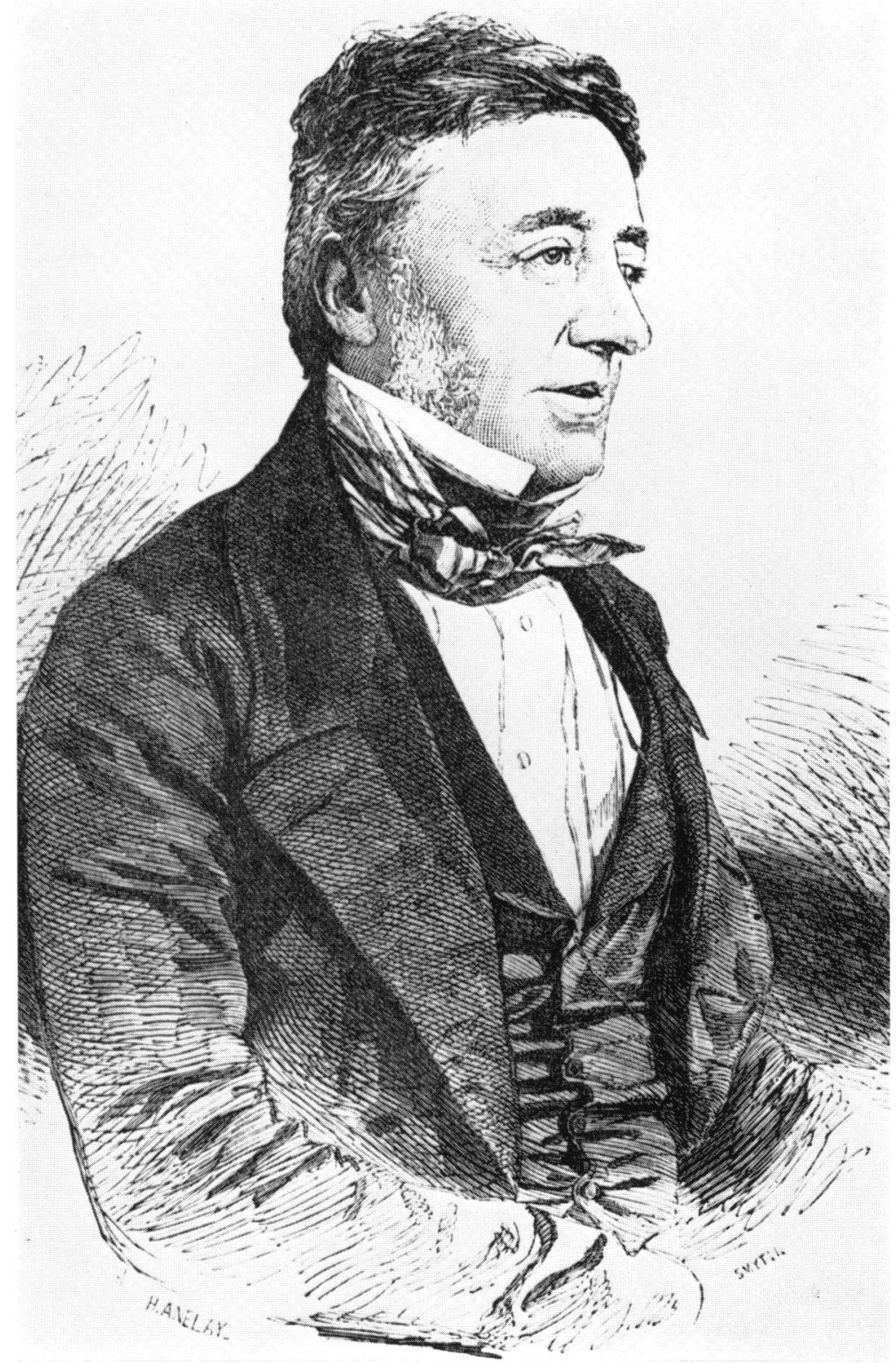

Fig. I

Bransby Cooper, about i850, from a daguerrotype taken by Mr. Mayall.

(Reproduced from the Lancet) 


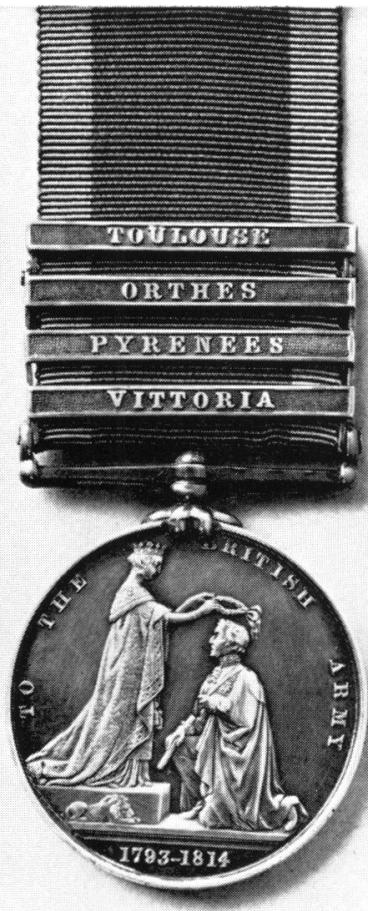

Fig. 2

The Military General Service Medal awarded to Bransby Cooper. 


\section{Nerws, Notes and Queries}

to Guy's Hospital. The purpose of this paper is to briefly describe his military service and to illustrate the medal he received.

While still at school at Yarmouth he decided to join the Navy so in 1805 , when aged thirteen, he was appointed midshipman to the Stately where he briefly served at Texel but his enthusiasm was no match for sea-sickness which forced him to return to school.

Persuaded by his uncle, Sir Astley Cooper, to study medicine he entered the Norfolk and Norwich Hospital as a pupil of Edward Rigby and Edward Colman. Late in $18 \mathrm{I}$ i he came to London and, as his uncle's pupil, joined the United Borough Hospitals where he completed two sessions. Before taking the examination of the College of Surgeons, Astley Cooper suggested that he should join the army to gain experience in the Peninsular War.

On 20 May, 1812 he was appointed temporary Assistant Surgeon in the Ordnance Medical Department. This Department was quite distinct from the Army Medical Department, for in 1801 the medical officers of the Royal Regiment of Artillery and Brigade of Horse Artillery were formed into a separate establishment and up to 1804 received warrants from the Master-General of Ordnance. After that date they received Commissions from the Crown and after 1814 the Ordnance Medical Department was separately listed in the Army List. It was not until 1853 that the two medical departments were merged into one with a single Director-General.

Cooper became 2nd Assistant Surgeon on 2 December, 1812 and remained in that rank until he was placed on half-pay on I April, 1816. He saw considerable service in Spain and France where he served at the battles of Vittoria (21 June, 1813), Pyrenees (28 July to 2 August, 1813), Orthes (27 February, 1814) and Toulouse (ro April, 1814).

In an excellent biography in the Lancet (1850) and in Plarr (1930) it is stated that Cooper also served at the siege of St. Sebastian (August and September, 1813) and the passage of the Nivelle (10 November, 1813 ).

Mr. D. W. King, Librarian, War Office, was kind enough to examine for me the original claim in the Public Records Office which Cooper submitted for his medal and found that he only listed Vittoria, Pyrenees, Orthes and Toulouse. This claim was allowed and these are the bars attached to his medal. Had Cooper served at St. Sebastian and Nivelle he would have added these to his original claim; it can, therefore, be assumed that he was not present at these engagements.

As a junior medical officer serving on the field Cooper must have had little opportunity to further his knowledge of practical surgery but later in life he mentioned several patients on whom he had performed amputation following gunshot wounds.

While waiting for return to England he was persuaded to join a force leaving for Canada and although he was most anxious to resume his interrupted studies he agreed to this extension of his service and embarked at Bordeaux. He arrived in Canada some time in August, 1814, for his name first appears in the Monthly Returns for that month and there he served until 1815 when a large force left Canada for England between 25 May and 24 June. It is possible he sailed with the Royal Artillery detachment on the transport Glory. Unfortunately, it has not been possible to find out exactly where he served in Canada. On his arrival in England in July 1815 he found that his brother had been apprenticed to his uncle, so Bransby went to Edinburgh where he matriculated and stayed for some time but late in 1816 , following the sudden death of his brother, Bransby resumed his surgical studies in London with his uncle. It is interesting to note that he did not become a Member of the Royal College of 
Surgeons until 5 December, 1823 . Later, on I I December, 1843 , he became one of the original 300 Fellows of the College. From 1841 to 1848 he was Arris and Gale Lecturer and served as a member of the Council of the College from 1848 until his death in 1853 . Shortly before his sudden death he had delivered the Hunterian Oration.

At the time when the clinical schools of Guy's and St. Thomas's Hospitals separated Bransby was appointed lecturer in anatomy at Guy's where he taught with great success, being popular with the students. In 1825 he was appointed assistant surgeon to the hospital and later in the same year full surgeon, a position which he held until his death. He was elected a Fellow of the Royal Society on 18 June, 1829 .

It was a great pity that Bransby Cooper was so completely overshadowed in his surgical career by his famous uncle, whom he greatly revered and whose biography he published in 1843 . Had he been left to make his own place in contemporary surgery he would have done so with success; there is no doubt, too, that his life would have been happier.

\section{Military General Service Medal (I793-1814)}

The medal, struck in silver, was designed by W. Wyon, R.A. and shows, on the obverse side, the diademed head of the young Queen, the legend VICTORIA REGINA and the date of issue, 1848. The reverse side shows the Queen about to place a laurel wreath on the head of the kneeling Duke of Wellington. Beside the dais is a small British lion and in the exergue are the dates 1793-1814. The words TO THE BRITISH ARMY surround the figures. Bars were added to the medal for each engagement. The ribbon is crimson with narrow borders of dark blue. Each medal had the name, rank and unit stamped around the edge; this particular medal is named BRANSBY COOPER ASST. SURG. ORD. MED. DEPT.

\section{ACKNO WLEDGEMENTS}

Grateful thanks are due to Mr. D. W. King, Librarian, War Office for the trouble he took in tedious checking of records and to Lt.-Col. M. E. S. Laws, O.B.E., M.C. of Hove, Sussex, the authority on Royal Artillery history, for checking and supplying the information on Cooper's service in Canada.

\section{REFERENCES}

Anonymous (1850), 'Biographical sketch of Bransby Blake Cooper, Esq., F.R.S.,' Lancet, II, $270-6$.

Carter, T. (1861), 'Medals of the British Army'. 3 vols. London, Groombridge and Sons.

Gordon, L. L. (1947), British Battles and Medals. Aldershot, Gale and Polden.

Johnston, W. (1917), Roll of Commissioned Officers in the Medical Service of the British Army. Aberdeen, University Press.

Plarr, V. G. (1930), Plarr's Lives of the Fellows of the Royal College of Surgeons of England. Revised by Sir D'Arcy Power. 2 vols. Bristol, John Wright \& Sons.

Public Records Office, London. 'Monthly Returns for Canada', 1814, 1815 (WO 17/1518, $\mathrm{WO} / 7 / 1519)$.

Public Records Office, London. 'General Service Medal Claims' (WO 100/1).

$$
296
$$

